\title{
Modal Insan dan Agihan Pendapatan di Malaysia (Malay Version)
}

Iqbal $\mathbf{U}^{*}$

History Programme, Faculty of Social Sciences and Humanities, National University of Malaysia, Malaysia

*Corresponding author: Iqbal U, History Programme, Faculty of Social Sciences and Humanities, National University of Malaysia, UKM 43650, Bangi Selangor, Malaysia, Tel: 60389215555; E-mail: uqbah@siswa.ukm.edu.my

Received date: December 2, 2015; Accepted date: January 9, 2016; Published date: January 13, 2016

Copyright: () 2016 Iqbal U. This is an open-access article distributed under the terms of the Creative Commons Attribution License, which permits unrestricted use, distribution, and reproduction in any medium, provided the original author and source are credited.

\section{Commentary}

In order to achieve a status of developed country, the Malaysian government carried out various measures in the economic, political and social aspects. The clear thing to us is that the economic aspect is emphasized because it is considered as the engine of economic growth and development that is able to accelerate the achievement of developed countries. Generally, this book is divided into two parts, namely the writing of which is based on secondary data obtained from official government data and the writing of which is based on primary data collected through field work in 2007/2008. This book contains nine chapters and the discussion is focused on the impact of human capital on the level and distribution of household income and individuals in Malaysia. The power of human capital in developing countries cannot be question. The educated population leaves greater impact on the increase in the social, political and economic growth of a country. In view of this problem various approaches have been made and various measurements were used.

Human capital is measured using a variety of approaches, including measures of human capital components separately and also formed a human capital index. Similarly, the distribution of income, measurement used is the percentage of income or wages received by households or individuals. In addition, the impact of human capital on wage differentials and income working individuals are analyzed in detail. Given the close relationship between human capital and social capital, especially in developing quality human, social capital aspects are also discussed in this book. Component of social capital such as networks and confidence to be processed in detail and subsequently formed the social capital index. The role of social capital in determining the level of household income and individual work also examined in this book. To further strengthen the argument about the positive qualities of the human relationship with the distribution of income, the human quality index is formed by combining human model component with of social capital component.

The content of this book in detail are as follows. Chapter one is an introduction to explain the concept of human capital, social capital and income distribution. This chapter also describes the relationship of human capital to economic development. In addition, the relationship between income distribution, economic growth and economic development are discussed in detail. It was followed by Chapter two that deepen the theory of human capital and social capital. The theory of income distribution and wage discrimination are also discussed in this chapter. At the end of this chapter talks about income distribution measurement method. In addition human quality that combined human capital and social capital also shelled in this chapter. Chapter three will discuss the progress and achievements of human capital in Malaysia. Investment in human capital components such as education, training and health in Malaysia is described in detail. In addition, enrollment and graduates from various levels and education flow are also discussed to see the effect of the investment in human capital. The discussion in this chapter continues with viewing the trend of the labor force, employment and skills development in Malaysia. It aims to strengthen the analysis of the impact of human capital investments that have been made [1].

Chapter four discusses government policies and strategies for human capital investment and income distribution. The next discussion is about the trend of income distribution in Malaysia, which focuses on income distribution of households and individuals. Writing in Chapter five focuses on the study data that was performed on 4003 households in Peninsular Malaysia in 2007/2008. Profile of respondents and the achievement of human capital, social capital and the distribution of income among those are reviewed in detail. A description of the formation of human capital index and the social capital performed in Chapter six. Components of human capital combined with other social capital components to form the index of human qualities. While Chapter seven and Chapter eight are the essence of this book in answering the question of the title of this book. Both this chapter analyzes the impact of human capital, social capital and human qualities and this three capital index in influencing the level and distribution of income.

In Chapter seven the impact of these three components are analyzed on the distribution of household income and individual work. The writing focus of Chapter eight are the impact of human capital on the difference in wages and household income and individual work. Apart from the impact separately, the impact of human capital index that was formed on the distribution of income is also analyzed. This book is useful to many parties such as policy makers, students and the general public. For policy makers, the invention described in this book can serve as a guide in formulating appropriate policy development and investment in human capital and income distribution. For students, the material in this book is useful as a reference when they want to complete their assignments or writing, even to the trainers, contents in this book can be used as teaching material in the case of Malaysia. For the general public, they can get knowledge about the achievements of human capital and its impact on income distribution in Malaysia.

\section{References}

1. (2011) Penerbit Universiti Kebangsaan Malaysia, Selangor pp: 211. 